Journal of Engineering and Applied Sciences 15 (5): 1133-1139, 2020

ISSN: 1816-949X

(C) Medwell Journals, 2020

\title{
Assessment of Pollution Load Capacity and Control Strategy in the Surabaya River using QUAL2KW and AHP Method
}

\author{
${ }^{1}$ Moh Sholichin and ${ }^{2}$ Shatirah Akib \\ ${ }^{1}$ Department of Water Resources Engineering, Faculty of Engineering, \\ Brawijaya University, 65141 Malang, Indonesia \\ ${ }^{2}$ Department of Civil Engineering, School of Architecture Design and the Built Environment, \\ Nottingham Trent University, NG1 4FQ Nottingham, United Kingdom
}

\begin{abstract}
A study of the water quality in the Surabaya river is conducted because of its function as the drinking water supply for the city of Surabaya as well as its support of agriculture, fisheries, livestock, industry and commerce. The site study is located along $\pm 41 \mathrm{~km}$ from the Mlirip dam to the Jagir dam which has a catchment area of $\pm 300 \mathrm{~km}^{2}$. The complexity of the problems that have occurred so far has caused a decrease in the quality and quantity of the Surabaya river water. Therefore, an effort to determine the pollution load capacity and control pollution strategy is needed. Data analysis uses the QUAL2Kw program application to calculate the pollution load that enters the Surabaya river. Analysis of priorities for water pollution control strategies uses the Analytic Hierarchy Process (AHP) method. The Surabaya river is divided into seven segments based on hydraulic data analysis, water quality and pollutant sources. The main parameters used in the QUAL2Kw simulation are BOD, COD and TSS. The analysis result of the maximum pollutant load for BOD parameters is $9,161 \mathrm{kgday}^{-1}$, COD is $45,831 \mathrm{kgday}^{-1}$ and TSS is $427,079 \mathrm{kgday}^{-1}$. The maximum pollution load capacity for BOD parameters is $6,958 \mathrm{kgday}^{-1}$, COD is $42,763 \mathrm{kgday}^{-1}$ and TSS is $420,167 \mathrm{kgday}^{-1}$. Based on the results of the AHP program, reducing the pollutant load and increasing the capacity of the Surabaya river can be determined through the following stages, namely: tightening waste disposal permits, industrial guidance and supervision, construction of domestic communal WWTPs, development of WWTP industrial area, enforcement of environmental law and socialization of riverbank communities.
\end{abstract}

Key words: Pollution load, control strategy, QUAL2KW, AHP program, determined, environmental law

\section{INTRODUCTION}

Urbanization always gives negative and positive influences to the development in any sector. The negative impact of the urbanization process is environmental problems such as flooding, loss of biodiversity and degradation of aquatic ecosystems (Bevilacqua and Braglia, 2000).

Numerous studies have suggested that the quality of surface water is affected by the characteristics of the soil cover with in a drainage area (Fatnasari and Hermana, 2010; Handoko, 2005; Herera, 2013; DME., 2003). The occurrence of ecosystem damage can be caused by a decrease in dissolved oxygen concentration due to degradation of pollutants by microorganisms, chemical oxidation and respiration of plants, algae and phytoplankton (MEF., 2004). The impact of low DOC can cause fish death and other diseases, odor and other aesthetic damage. In previous local research conducted by Masduqi and Apriliani (2008) and Syafi'i and Masduqi (2011) (Miller, 1975), the Surabaya river's water pollution load has exceeded the established quality standard numerous times. Pollutants in the Surabaya river are mainly sourced from domestic, industrial and agricultural waste (Masduqi and Apriliani, 2008).

According to the Decree of the State Minister of Environment No. 110 of 2003, the computational method can be used in determining the capacity of water pollution load. Computational methods are mathematical models run through a computer simulation such as the QUAL2Kw Model. The QUAL2Kw Model is very efficient and able to model river water quality from upstream to downstream (Nurmayanti, 2002). In addition, the QUAL2Kw Model can simulate transport and the presence of pollutants in the water. This model simulates rivers in one-dimensional form with non-uniform flow and fixed flow as well as a river based on the impact of two sources, originating from point sources and non-point sources (RIG., 2001).

The QUAL2Kw Model can simulate $\mathrm{pH}$ parameters, alkalinity, inorganic suspended solids, pathogenic bacteria, algae, temperature, fast-reacting $\mathrm{BOD}$, slow-reacting BOD, Dissolved Oxygen (DO),

Corresponding Author: Moh Sholichin, Department of Water Resources Engineering, Faculty of Engineering, Brawijaya University, 65141 Malang, Indonesia 
Table 1: Technical simulation scenario

\begin{tabular}{lllll}
\hline Simulation & Upstream water conditions & River data & Pollution source & River water quality \\
\hline 1 & Existing & Existing & Existing & Model \\
2 & Existing & Existing & No polluters & Model \\
3 & Existing & Existing & Trial and error & Class II WQS \\
4 & Meet class II WQS & Existing & Existing & Model \\
5 & Meet class II WQS & Existing & No polluters & Model \\
6 & Meet class II WQS & Existing & Trial and error & Class II WQS \\
\hline
\end{tabular}

phytoplankton, organic and inorganic phosphorus, organic nitrogen, NH4+ nitrogen, $\mathrm{NH} 3$ - nitrogen, conductivity, pathogenic bacteria and alkalinity (RIG., 2001). River water pollution control strategy for the Surabaya river is based on analysis of survey results with the Analytic Hierarchy Process (AHP) method. AHP is an approach used to make effective decisions through structuring multiple criteria into hierarchies, assessing the relative importance of each criterion, compare alternatives for each criterion and determine all rankings of alternatives (Pelletier and Chapra, 2008). This study aims to determine the pollution load capacity with various pollution load reduction and control pollution strategies in the Surabaya river.

\section{Theory and formula}

Use of QUAL2Kw: The first step in modeling using QUAL2KW is to input the obtained water quality, point source and non-point source data into the QUAL $2 \mathrm{Kw}$ worksheet.

The model is run repeatedly until the model results are obtained according to the actual conditions. Model adaptation is done by "trial and error" model coefficient value. The appropriate model can be verified and used to simulate a predetermined scenario. The scenario in this study can be seen in Table 1. Explanation of Table 1 for the four simulations used in this study are as follows:

Scenario 1: In this scenario, the data inputted in the program is the existing data on water quality from upstream. Data is obtained from uncertain pollutant sources and certain pollutant sources. The source of uncertain pollutants comes from household waste that enters the river which is estimated from the total population multiplied by the emission factor. While certain pollutant sources come from industry (the load of waste comes from industrial effluents that lead directly to the river). The waste load from the drainage channel and others is assumed to be an indeterminate source.

Scenario 2: In this scenario, the quality of water in the upstream of the Surabaya river is in accordance with the existing data. Meanwhile, it is assumed that there is no source of pollution entering the Surabaya river, neither from industrial waste nor domestic waste.

Scenario 3: In this scenario, the quality of water in the upstream of the Surabaya river is in accordance with the class II water quality standard in PP No. 82/2001. This scenario is done using "trial and error". This scenario is used to calculate the capacity of the river.

Scenario 4: This scenario is the same as scenario 1 but the quality of water in the upstream of the Surabaya river is considered to be in accordance with the class II water quality standard in PP No. $82 / 2001$. This scenario is intended to eliminate pollution occurring in rivers or water entering the Surabaya river, namely water entering from the Brantas river watershed.

Scenario 5: This scenario is the same as scenario 2 but water quality in the upstream of the Surabaya river is considered to be in accordance with class II water quality standards in PP No. 82/2001.

Scenario 6: This scenario is the same as scenario 3 but water quality in the upstream of the Surabaya river is considered to be in accordance with class II water quality standards in PP No. 82/2001.

Capacity is determined using scenario 2 (without pollutants) and scenario 3 (maximum pollutant load). Capacity is the difference between full pollutant load and without pollutants.

\section{MATERIALS AND METHODS}

AHP method is a model introduced by Thomas L. Saaty in 1971. Saaty states that AHP is a model for building ideas and defining problems by making assumptions and obtaining desired solutions and the model allows testing of results sensitivity. Stages of analyzing the data are as follows (Saaty, 1999):

- $\quad$ System identification, namely to identify problems and determine the desired solution

- Compilation of hierarchical structures beginning with general objectives, followed by sub-objectives, criteria and possible alternatives at the lowest criteria level

Pair wise comparisons, describe the relative influence of each element on each goal and the criteria above. Pairwise comparison techniques used in AHP are based on "judgment" or the opinions of respondents who are considered "key persons". 
Determination of the level of importance at each level of the hierarchy of opinions is carried out using pairwise comparisons techniques. Pairwise comparisons techniques compare elements in pairs, so that, the value of the interests of each department is obtained. Assessment is carried out by giving numerical weight to each element compared to the results of direct interviews with respondents. To quantify qualitative data, a paired appeal scale is used (Saaty, 1999). For an individual opinion matrix, the formulation can be presented in Table 2 .

In this case $\mathrm{Cl}, \mathrm{C} 2, \ldots, \mathrm{Cn}$ is a set of elements at one level inside the hierarchy. Quantification of opinions from the results of pairwise comparisons form a matrix $n \times n$. Aij value is the value of the matrix of the results of the comparison that reflects the value of Ci's interest in $\mathrm{Cj}$.

Combined opinion matrix, a new matrix whose elements originate from the geometric average of individual opinion matrix elements whose inconsistency Ratio (CR) is eligible. The purpose of the preparation of opinion matrices is to measure the level of consistency and priority vectors of hierarchical elements that represent all respondents.

Horizontal processing, namely: multiplication of lines; calculation of priority vector or feature vector (eigen vector); maximum eigen value calculation and calculation of inconsistency ratios. The consistency measurement value is needed to calculate the consistency of the respondent's answers. Vertical processing, used to prioritize the influence of each element at the hierarchy level of certain decisions on the main target.

\begin{tabular}{lllll}
\multicolumn{2}{l}{ Table 2: Individual opinion matrix } \\
\hline $\mathrm{A}=$ (aij) & $\mathrm{C} 1$ & $\mathrm{C} 2$ & $\ldots$ & $\mathrm{Cn}$ \\
\hline $\mathrm{C} 1$ & 1 & $\mathrm{~A} 12$ & $\ldots$ & $\mathrm{A} 1 \mathrm{n}$ \\
$\mathrm{C} 2$ & $1 / \mathrm{A} 12$ & 1 & $\ldots$ & $\mathrm{A} 2 \mathrm{n}$ \\
$\ldots$ & $\ldots$. & $\ldots$ & $\ldots$ & $\ldots$ \\
$\mathrm{Cn}$ & $1 / 1 \mathrm{n}$ & $1 / 2 \mathrm{n}$ & $\ldots$ & 1 \\
\hline
\end{tabular}

Revision of opinion, can be done if the value of the opinion inconsistency ratio is quite high $(>0.1)$. The use of this revision is very limited considering the deviation from the actual answer. The following are the steps using the AHP method as a basis for decision making (Saaty, 1999):

- Define the problem and determine the desired solution or goal

- Determine the criteria

- Determine the alternative

- Spread the questionnaire to the relevant respondents

- Compile a matrix of the average results obtained from a number of respondents. Then the results are processed using Expert Choice Version 2000

Analyze the results of Expert Choice version 2000 to find out the results of inconsistency and priority values. If the consistency value is more than 0.10 , then the result is inconsistent but if the value is $<0.10$, then the result is said to be consistent. Determine the priority scale of the criteria and alternatives to achieve the goal.

\section{Experimental setup}

Study area: The Surabaya river is located in the East Java province in Indonesia which is downstream from the Brantas river watershed. This study of the Surabaya river is carried out from upstream to downstream which has a length of $42.3 \mathrm{~km}$ from the Mlirip dam (segment 1) to the Jagir dam (segment 7) Fig. 1.

The segment determination is based on segments that have been used in secondary data and waste water input. Segments are also determined based on the physical and hydraulic characteristics of the Surabaya river namely the transverse profile of the river, the Surabaya river

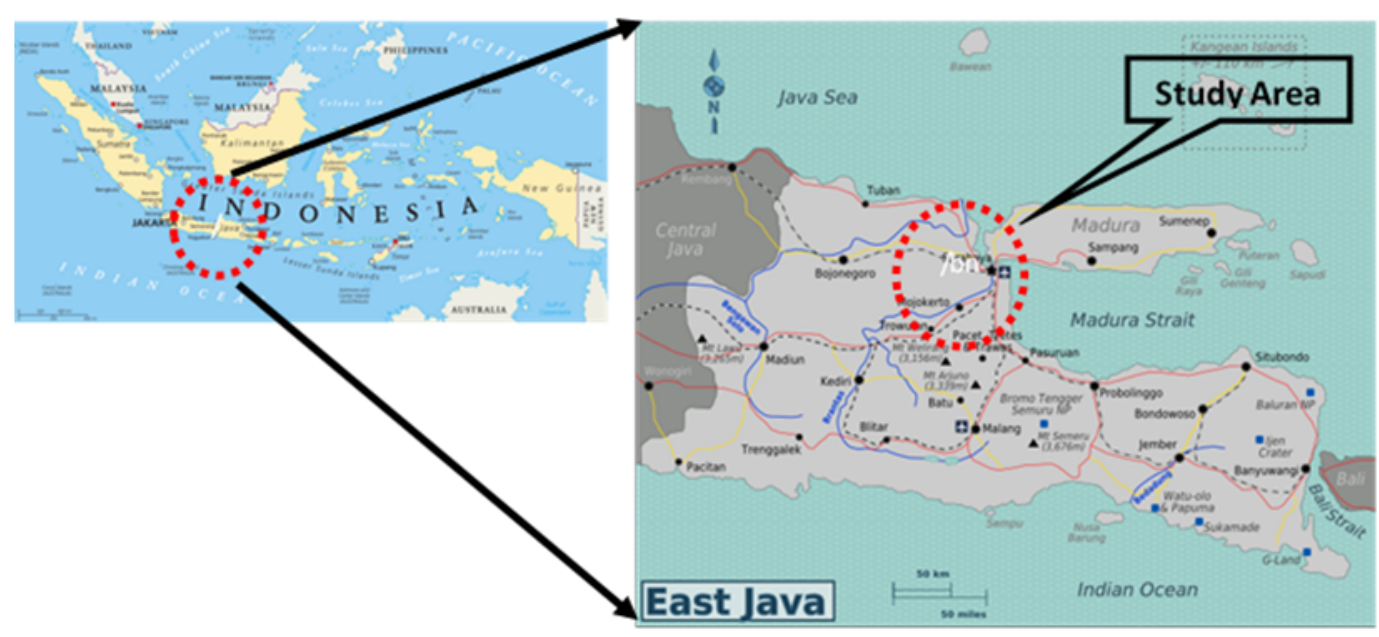

Fig. 1: Study area of the Surabaya river, Indonesia 
Table 3: Paired appeal scale

\begin{tabular}{|c|c|c|}
\hline Value & Definition & Explanation \\
\hline$\overline{1}$ & Both factors are the same importance & Two elementshave the same effect towards the goal \\
\hline 3 & $\begin{array}{l}\text { Factor one a little more important than } \\
\text { another factor }\end{array}$ & $\begin{array}{l}\text { Experience and assessment is very strong, support one } \\
\text { element compared to other element }\end{array}$ \\
\hline 5 & $\begin{array}{l}\text { Factor one essential or more important } \\
\text { than another factor }\end{array}$ & $\begin{array}{l}\text { One element strongly supported and dominantly } \\
\text { involved in practice }\end{array}$ \\
\hline 7 & $\begin{array}{l}\text { Factor one obviously more } \\
\text { important than another factor }\end{array}$ & $\begin{array}{l}\text { Supporting evidence for element one } \\
\text { against other element have highest } \\
\text { affirmation level which might strengthen }\end{array}$ \\
\hline 9 & $\begin{array}{l}\text { Factor one absolutely more } \\
\text { important than another factor }\end{array}$ & $\begin{array}{l}\text { This value is given if there are two } \\
\text { compromises between two choices }\end{array}$ \\
\hline $2,4,6,8$ & $\begin{array}{l}\text { Between values, between two value } \\
\text { consideration adjacent }\end{array}$ & - \\
\hline Opposite value & $\begin{array}{l}\text { If for activities } i \text { got number } 2 \text {, if } \\
\text { compared with } j \text { activity, then } j \text { has a } \\
\text { value of } 1 / 2 \text { compared to } i\end{array}$ & - \\
\hline
\end{tabular}

Table 4: Coordinate points for the Surabaya river segments

\begin{tabular}{lrc}
\hline Reach & Section & Length $(\mathrm{km})$ \\
\hline Mlirip-Perning & $42.30-35.30$ & 7.0 \\
Perning-Legundi & $35.30-24.00$ & 11.3 \\
Legundi-Cangkir & $24.00-15.90$ & 8.1 \\
Cangkir-Bambe & $15.90-11.70$ & 4.2 \\
Bambe-Sepanjang & $11.70-7.90$ & 3.8 \\
Sepanjang-Gunungsari & $7.90-2.40$ & 5.5 \\
Gunungsari-Jagir & $2.40-0.00$ & 2.4 \\
\hline
\end{tabular}

water flow and the presence of tributaries. Determination of segments and their coordinates can be seen in Table 3 and 4.

Data collection: Data collection is divided into two: namely, primary data and secondary data. The primary data includes water quality parameter data such as BOD and COD and discharge. Secondary data includes the catchment of the Surabaya river; climatological data (air temperature and wind speed); hydraulic data (river length, river width, river discharge, flow velocity and river depth); Surabaya river water quality data from 2011-2018; the number of industries and the number of people around the Surabaya river, especially, around the Bambe Canggu-Tambangan bridge segment.

Sampling: Surabaya river water discharge from December to May based on measurements taken at some monitoring points shows a large value, between 50-100 $\mathrm{m}^{3} \mathrm{sec}^{-1}$. Sampling methods are based on Indonesia National Standard (SNI) 6989-57-2008. For rivers with a flow between $5-150 \mathrm{~m}^{3} \mathrm{sec}^{-1}$, samples are taken at two points, each at a distance of $1 / 3$ and $2 / 3$ the width of the river and at a depth of zero, five times the depth of the surface or taken by an integrated sampler, so that, water samples are obtained evenly from the surface to the bottom and then mixed.

River segmentation: The Surabaya river has a length of $42.3 \mathrm{~km}$ but this study is limited to Jagir. The section used for modeling needs is divided into several segments, starting from $27.78 \mathrm{~km}$ (Canggu bridge) to $0 \mathrm{~km}$ (Tambangan Bambe).
Segments 1-2 $(3.78 \mathrm{~km})$ : The initial or upstream segment of the river from $27.78-24 \mathrm{~km}$. Segment $1-2$ is divided based on river water quality characteristics with input of industrial waste, agricultural waste and domestic waste as well as with changes in river hydraulics.

Segments 2-3 (11.9 km): Segments 2-3 are from 24-12.10 km. Segments 2-3 are divided based on river water quality characteristics with input of industrial waste, agricultural waste and domestic waste.

Segments 3-4 $(8.5 \mathrm{~km})$ : Segments 3-4 are from 12.10-3.6 km. Segments 3-4 are divided based on river water quality characteristics with input of domestic waste and industrial waste.

Segments 4-5 $(3.6 \mathrm{~km})$ : Segments 4-5 are from 3.6-0 km. Segments 4-5 are divided based on river water quality characteristics with input of domestic waste, industrial waste and tributaries.

Model development: The construction of the model has two stages, namely the construction of hydraulic parameters and water quality. The hydraulic parameters modeled are river depth, river flow and discharge velocity. For water quality, the parameters are temperature, $\mathrm{pH}$, ammonium, phosphate, nitrate, $\mathrm{BOD}$, DO and TSS. The development of the model begins with inputting data on the sheets found in the QUAL2Kw program, then clicking the "Run VBA" button. The inputted data will form a model in the form of a graph. The model is said to be correct if it has approached the value on the monitoring data (black dot). If the model has not been formed, then trial and error is done.

Model verification: Model verification is intended to make a model that approaches data. Model verification needs to be done because of variations in data at different times, both on river water quality and wastewater quality. Verification is done with the formation of a model but the 
data used is different. After the model is verified, the model can be used to simulate the scenario found in Table 1.

Strategic scenarios with AHP method: The strategy for controlling water pollution requires a series of criteria and alternatives to achieve the desired goals according to the conditions and capabilities of existing resources. It needs to be formulated based on in-depth interviews with key-person and analysis based on the AHP method. Criteria and alternatives for achieving the objectives of the water pollution control strategy are prepared based on the results of field surveys and discussions with people who are competent in the water pollution control policing. The main aspect that relating to the strategy of water pollution control are:

- Planning management aspects

- Institutional social aspects

- Environmental aspects

The opinions of the key-person are later analyzed and quantified with AHP tools and lead to analysis of the three aspects relating to control strategies of water pollution.

\section{RESULTS AND DISCUSSION}

Water quality in Surabaya river: Data on water quality from industrial pollutant sources is obtained from the results of monthly water quality monitoring conducted by BLH East Java province. The complete Surabaya river water quality data can be seen in Table 5 .

Model construction: The results of the model construction for hydraulic parameters can be seen in Fig. 2 and 3.

Water quality simulation: The Surabaya river water quality model that has been obtained is then used to simulate scenario 1 through scenario 6 . The scenario used to calculate the capacity of the Surabaya river has upstream conditions in accordance with existing conditions such as scenario 2 and scenario 3 . Scenario 2 states the condition of the Surabaya river without pollutants while scenario 3 states the condition of the
Surabaya river with full pollution load according to the class II water quality standard. Pollution load is calculated by multiplying inflow discharge with concentration contained in the worksheet source summary. Pollution load for scenario 2 can be seen in Table 6 while pollution load for scenario 3 can be seen in Table 7. The simulation results of scenario 3 are as follows (Fig 4-7):

Capacity: Determination of capacity is the calculation of the difference between the condition of the river with full

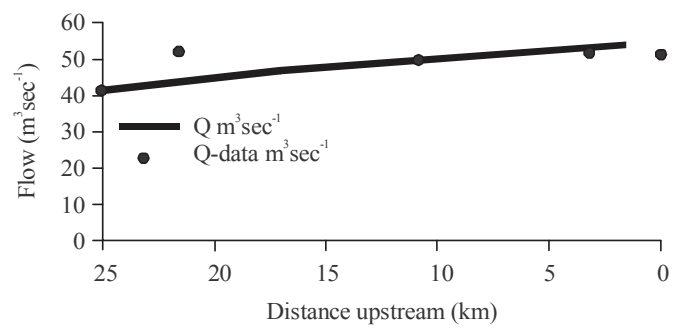

Fig. 2: Comparison model and data flow $\left(\mathrm{m}^{3} \mathrm{sec}^{-1}\right)$

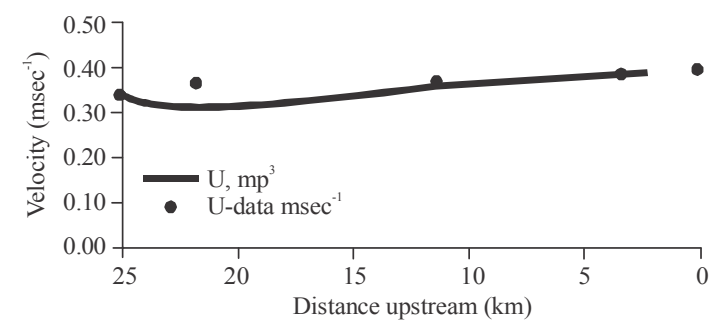

Fig. 3: Comparison model and data velocity $\left(\mathrm{msec}^{-1}\right)$

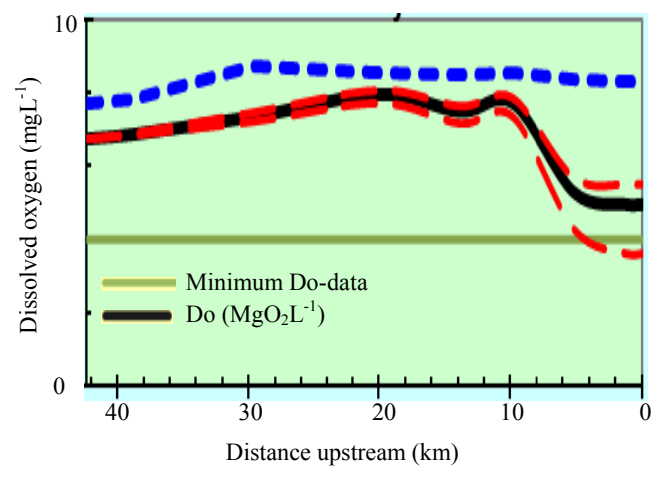

Fig. 4: DO Profile of the Surabaya river based on scenario 3 (Kali Surabaya 2018)

Table 5: Average Surabaya river water quality for 2011-2017

\begin{tabular}{lccccc}
\hline No. segment & $\mathrm{pH}$ & $\mathrm{DO}\left(\mathrm{mgL}^{-1}\right)$ & $\mathrm{TSS}\left(\mathrm{mgL}^{-1}\right)$ & $\mathrm{BOD}\left(\mathrm{mgL}^{-1}\right)$ & $\mathrm{COD}\left(\mathrm{mgL}^{-1}\right)$ \\
\hline 1 & 7.79 & 6.75 & 114.98 & 4.41 & 10.47 \\
2 & 7.79 & 7.02 & 140.80 & 4.52 & 10.92 \\
3 & 7.78 & 6.65 & 183.60 & 5.20 & 12.87 \\
4 & 7.73 & 7.40 & 139.72 & 5.48 & 13.58 \\
5 & 7.71 & 5.93 & 123.04 & 5.19 & 13.01 \\
6 & 7.67 & 5.56 & 175.71 & 4.74 & 11.75 \\
7 & 7.61 & 5.71 & 160.54 & 4.75 & 11.16 \\
\hline
\end{tabular}


Table 6: Pollution load scenario $\left(2 \mathrm{kgday}^{-1}\right)$

\begin{tabular}{llll}
\hline Reach & BOD $\left(\mathrm{kgday}^{-1}\right)$ & COD $\left(\mathrm{kgday}^{-1}\right)$ & $\mathrm{TSS}\left(\mathrm{kgday}^{-1}\right.$ \\
\hline Segment 1 & 247 & 501 & 3,828 \\
Segment 2 & 9,161 & 37,498 & 37,7895 \\
Segment 3 & 586 & 927 & 1598 \\
Segment 4 & 3,422 & 12,706 & 9,930 \\
Segment 5 & 2,195 & 17,628 & 427,079 \\
Segment 6 & 5,014 & 45,831 & 17,132 \\
Segment 7 & 666 & 1,103 & 3,004 \\
\hline
\end{tabular}

Table 7: Pollution load scenario $\left(3 \mathrm{kgday}^{-1}\right)$

\begin{tabular}{llll}
\hline Reach & BOD $\left(\mathrm{kgday}^{-1}\right)$ & COD $\left(\mathrm{kgday}^{-1}\right)$ & $\mathrm{TSS}\left(\mathrm{kgday}^{-1}\right)$ \\
\hline Segment 1 & 150 & 340 & 466 \\
Segment 2 & 2,203 & 18,360 & 36,720 \\
Segment 3 & 130 & 520 & 650 \\
Segment 4 & 259 & 2,160 & 4,167 \\
Segment 5 & 414 & 3,456 & 6,912 \\
Segment 6 & 803 & 3,067 & 12,802 \\
Segment 7 & 250 & 560 & 760 \\
\hline
\end{tabular}

Table 8: Capacity of the Surabaya river $\left(\mathrm{kgday}^{-1}\right)$ based on scenario 3

\begin{tabular}{llll}
\hline Reach & BOD $\left(\mathrm{kgday}^{-1}\right)$ & $\mathrm{COD}\left(\mathrm{kgday}^{-1}\right)$ & $\mathrm{TSS} \mathrm{kgday}^{-1}$ \\
\hline Segment 1 & 247 & 501 & 3,828 \\
Segment 2 & 6,958 & 19,138 & 341,175 \\
Segment 3 & 586 & 927 & 1,598 \\
Segment 4 & 3,163 & 10,546 & 5,762 \\
Segment 5 & 1,780 & 14,172 & 42,0167 \\
Segment 6 & 4,210 & 42,763 & 4,329 \\
Segment 7 & 666 & 1,103 & 3,004 \\
\hline
\end{tabular}

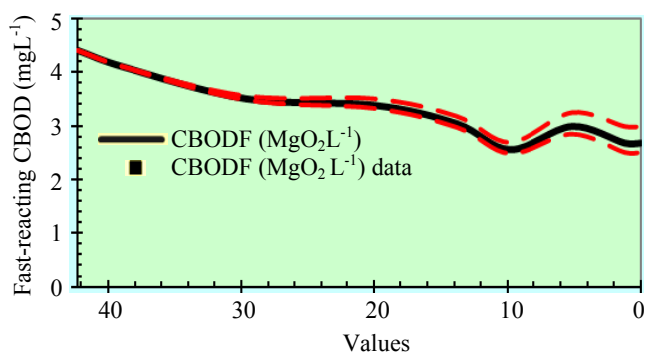

Fig. 5: BOD profile of the Surabaya river based on scenario 3

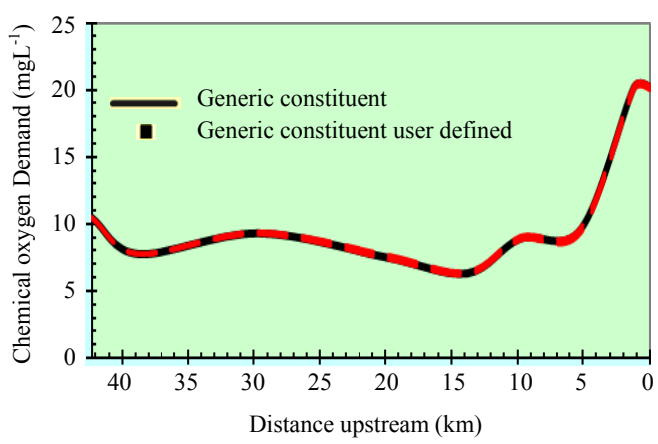

Fig. 6: COD profile of the Surabaya river based on scenario 3

load (scenario 3) and the condition of the river with no pollution (scenario 2). The results of the calculation of capacity can be seen in Table 8 . The results of the

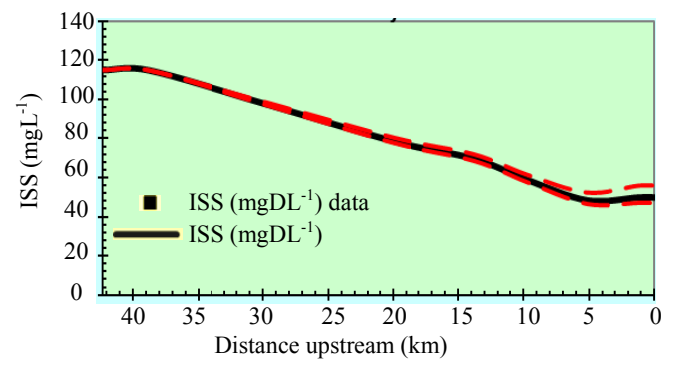

Fig. 7: TSS profile of the Surabaya river based on scenario 3

calculation of the capacity in Table 8 show that the capacity of the pollution load for ammonium and nitrate parameters is still large while for BOD, COD and TSS.

Strategy scenario results using AHP method: The results of the joint opinion analysis key-person, quantified by AHP on the three aspects related to water pollution control strategy, show that institutional social aspects need to be developed to control the water pollution in the Surabaya river with a priority value of weight 0.6 . Next, the management aspect of planning received a weight value of 0.19 and ecological aspects received a weight value of 0.15 . Inconsistency value amounting to 0.035 was below the maximum value of 0.1 , meaning the combined expert opinion resulted in consistent and acceptable analysis results.

The institutional social aspect becomes a priority in controlling water pollution due to the use of natural resources and environmental quality related to behavior patterns of the surrounding community. The condition and quality of the Surabaya river water are affected by the input of waste water from the catchment area and the water quality is further affected by community activity in the river. Management planning aspect becomes the second priority. This indicates that in the water pollution control strategy needs policy instruments that are used as guidelines in pollution control including division of roles between relevant agencies. Ecological aspects are the third priority. Efforts to prevent water pollution can be done through quality improvements of the environment around water sources.

To implement these programs, integrated and coordinated activities are needed along with master watershed-based resource management guidelines including the division of roles between agencies. Overall, the value of inconsistency ratio amounted to $0.04(<0.1$, limit maximum), so, the results of the opinion are consistent and the analysis can be accepted. The results of the AHP analysis can then be used as one consideration in formulating a strategy to control the Surabaya river water pollution. 


\section{CONCLUSION}

Based on the results of modeling using the QUAL2KW program, the capacity of the Surabaya river are as follows:

- The status of water quality in the Surabaya river is based on the STORET index value of all segments in the Surabaya river and is therefore included in the Status/Category D class (heavily polluted)

- The capacity of the Surabaya river BOD, COD and TSS parameters for each segment is as follows:

- The Mlirip-Perning segment: the BOD parameter is $247 \mathrm{kgday}^{-1}$, the COD parameter is 501 $\mathrm{kgday}^{-1}$ and the TSS parameter is $3,828 \mathrm{kgday}^{-1}$

- The Perning-Legundi segment: the BOD parameter is $6,958 \mathrm{kgday}^{-1}$, the COD parameter is $119,138 \mathrm{kgday}^{-1}$ and the TSS parameter is $341,175 \mathrm{kgday}^{-1}$

- The Legundi-Cangkir segment: the BOD parameter is $586 \mathrm{kgday}^{-1}$, the COD parameter is $927 \mathrm{kgday}^{-1}$ and the TSS parameter is 1,598 kgday $^{-1}$

- The Cangkir-Bambe segment: the BOD parameter is $3,163 \mathrm{kgday}^{-1}$, the COD parameter is 10,546 kgday $^{-1}$ and the TSS parameter is $5,762 \mathrm{kgday}^{-1}$

- The Bambe-Sepanjang segment: the BOD parameter is $1,780 \mathrm{kgday}^{-1}$, the COD parameter is $14,172 \mathrm{kgday}^{-1}$ and the TSS parameter is $420,167 \mathrm{kgday}^{-1}$

- The Sepanjang-Gunungsari segment: the BOD parameter is $4,210 \mathrm{kgday}^{-1}$, the COD parameter of $42,763 \mathrm{kgday}^{-1}$ and the TSS parameter is $4,329 \mathrm{kgday}^{-1}$

- The Gunungsari-Jagir segment: the BOD parameter is $666 \mathrm{kgday}^{-1}$, the COD parameter is $1,103 \mathrm{kgday}^{-1}$ and the TSS parameter is 3,004 kgday $^{-1}$

The strategies that need to be implemented so far are: greening, especially in the upstream areas of the eradicated watershed industrial guidance and supervision; construction of domestic communal WWTPs by the Government, especially, for people who live along the watershed. Improved coordination between agencies related to water pollution control. Improved coordination can be done by applying the principle requirements of water pollution control and having the planned business/activity apply for permission.

\section{ACKNOWLEDGEMENT}

I would like to express my appreciation to University of Brawijaya for support funding and Surabaya city officer for providing secondary data and interview season with local community.

\section{REFERENCES}

Bevilacqua, M. and M. Braglia, 2000. The analytic hierarchy process applied to maintenance strategy selection. Reliab. Eng. Syst. Saf., 70: 71-83.

DME., 2003. [Guidelines for determination of water quality status]. Decree of the Minister of Environment, Jakarta, Indonesia. (In Indonesian) http://www.ampl.or.id/digilib/read/pedoman-penen tuan-status-mutu-air/47415

Fatnasari, H. and J. Hermana, 2010. [Settlement waste water management strategyin the bearing of Kali Surabaya]. Proceedings of the 11th National Seminar on Technology Management (MMT-ITS'10), February 6, 2010, Surabaya, Indonesia, pp: D-5-1-D-5-8 (In Indonesian).

Handoko, I., 2005. Quantitative modeling of system dynamics for natural resources management. SEAMEO BIOTROP, Bogor, Indonesia.

Herera, A., 2013. [A study of determination of Surabaya river pollution load capacity using the QUAL2Kw program package]. Master Thesis, Brawijaya University, Malang, Indonesia. (In Indonesian)

MEF., 2004. [Government Regulation No. 82 of 2001: Water Quality Management \& Water Pollution Control]. Ministry of Environment and Forestry, Jakarta, Indonesia, (In Indonesian).

Masduqi, A. and E. Apriliani, 2008. Estimation of Surabaya river water quality using Kalman filter algorithm. IPTEK. J. Technol. Sci., Vol. 19, No. 3. 10.12962/j20882033.v19i3.145

Miller, G.T., 1975. Living in the Environment: Concepts, Problems and Alternatives. Wadsworth Publishing \& Company, Belmont, California, USA.,.

Nurmayanti, 2002. Contribution of domestic waste to water quality. BA. Thesis, Gajahmada University, Yogyakarta, Indonesia.

Pelletier, G. and S. Chapra, 2008. QUAL2Kw theory and documentation(Version 5.1): A modeling framework for simulating river and stream water quality. Environmental Assessment Program Olympia, Washington, USA.

RIG., 2001. Water quality management \& water pollution control. Government Regulations PP No. 82, ? Yogyakarta, Indonesia. http://www.ampl.or.id/ $\mathrm{digilib/read/pengelolaan-kualitas-air-}$ pengendalian-pencemaran-air/47668

Saaty, T.L., 1999. Decision Making for Leaders: The Analytical Hierarchy Process for Decisions in a Complex World. 3rd Edn., RWS Publications, Pennsylvania, USA.,.

Syafi'i, M. and A. Masduqi, 2011. Application of QUAL2Kw computer simulation model in Surabaya river water quality modeling study. B.Sc. Thesis, Sepuluh Nopember Institute of Technology (ITS), Surabaya, Indonesia. 